\title{
Stochastic Variability of Rainfall and its Impact on the Flooding Regime of the Zambezi Flood Plain
}

\author{
Joseph T. Mwale, Idani Lichilo, Racheal Luneta
}

\begin{abstract}
This research assesses the impact of rainfall variability on the flooding regime of the Zambezi floodplain as part of the scientific endeavour to understand the dynamics of hydrologic variability in natural systems such as riverine and floodplain ecosystems. In the context of global environmental change, hydro-climatic fluctuations are observed to be intensifying in magnitude and frequency with notable impacts on both human and natural systems. Understanding variability is important for the effective management of ecosystems which sustain human livelihoods. The study was conducted on a temporal scale of 50 years from 1965 to 2014 based on observed discharges and rainfall at the Chavuma National Gauge Station in the Zambezi district of Zambia. The research was guided by the hypothesis that there were no significant variations in the discharge on account of rainfall variability. Statistical methods of data analysis employed included exploratory, frequency and sensitivity analysis techniques. The results of the analysis revealed significant inter-annual variation of $21 \%$ in the discharge time series with a dominant periodicity of 10 years in its sinusoidal discharge signal. The sensitivity of the discharge to rainfall was found to be insignificant with a very low precipitation elasticity of streamflow of 0.03 . In view of these findings, the conclusion of the study is that the flooding regime of the Zambezi floodplain is seemingly robust against the variability of rainfall. However, further research needs to be undertaken to provide deeper insight into the changes in the flooding regime of the Zambezi floodplain taking into account a broader spectrum of natural and anthropogenic forcing, and to quantify the flooding regime for integrated wetland management linking the dynamics of flooding to the biological diversity in the ecosystem.
\end{abstract}

Index Terms - Flood plain, Flooding regime, Rainfall variability, Zambezi river.

\section{INTRODUCTION}

The Zambezi floodplain is one of Africa's great wetlands with a rich biological diversity providing a wide range of ecosystem goods and services. However, the functional landscape of the wetland is increasingly being threatened by natural and human-induced perturbations. Under the scenario of global environmental change in the Anthropocene period, hydro-climatic fluctuations appear to be intensifying in magnitude and frequency with notable impacts on both human and natural systems. Understanding variability is, thus, important for the integrated management of ecosystems in order to sustain their ecological integrity. This research

Joseph T. Mwale, School of Agriculture and Natural Resources, Mulungushi University, Kabwe, Zambia.

Idani Lichilo, School of Agriculture and Natural Resources, Mulungushi University, Kabwe, Zambia.

Racheal Luneta, School of Agriculture and Natural Resources, Mulungushi University, Kabwe, Zambia. assesses the impact of rainfall variability on the flooding regime of the Zambezi floodplain as part of the scientific endeavour to understand the dynamics of hydrologic variability in natural systems such as riverine and floodplain ecosystems. Central to the functionality of wetlands is the hydrologic variability which is linked in complex ways to the precipitation regime of the catchment area of the wetland. The focus of this research is the Zambezi floodplain, which is located in Zambia in Southern Africa, a region Fauchereau et al. [1] described as conducive to extreme weather events and great inter-annual variability of the hydrological cycle. Extreme hydrological events such as floods and drought are notably associated with variability of rainfall. A slight decrease in annual rainfall, along with increased inter-annual variability and an increase in extreme precipitation events have been observed for Zambia over a historical period of 40 years (IPCC [2]; Kirtman et al. [3]; Hulme et al. [4]; Reason et al. [5]). McSweeney and Lizcano [6] and Tadross et al. [7] reported a decrease in mean annual rainfall in Zambia at the rate of $1.9 \mathrm{~mm}$ per month per decade and shortening of the crop growing season. Under the climate change scenario, the scientific consensus on the future of rainfall patterns in Zambia is that inter-annual variability is expected to increase along with a slight decrease in rainfall amount [8].

The research is founded within the theoretical framework of the flood pulse concept [9] and the natural flow paradigm [10], which have significantly contributed towards the understanding of the hydrological characteristics of rivers and their ecological processes. As such it is understood that streamflow in rivers can be described using five basic characteristics including magnitude, frequency, duration, period of occurrence and variability; and the hydrographs of individual rivers are influenced by a series of partly interacting factors, such as climate, gradients, landscape morphology, floodplain buffering and human impacts, which together cause very complex patterns. This knowledge is essential to natural resources management. However, as Poff et al. [10] observed, the natural resources management approaches often fail to recognize the fundamental scientific principle that the integrity of flowing water systems depends largely on their natural dynamic character. This is emphasized by Booth and Viers [11], who called for further understanding of the seasonal and inter-annual hydrologic variability in order to better manage water resources and maintain ecosystem services provided by rivers and their floodplains. Floodplain ecosystems are among the most valuable biomes worldwide (Costanza et al. [12]; and Mitsch and Gosselink [13]. The ecosystem services include water 
purification and storage, flood attenuation, food production, and habitat formation, most of which are essential for both humans and animals [14]. Since many floodplains have recreational, cultural and aesthetic values, they are protected by the Ramsar Convention, an intergovernmental treaty on the conservation of wetlands of international importance.

In hydrologic terms, floodplains are periodically inundated areas occurring in the transition zones between the aquatic and terrestrial earth's surface. The periodic nature of the flooding is characterized by a flood pulse, which Junk et al. [15] identified to be the principal driving force responsible for the existence, productivity and interactions of the major biota in river floodplain systems. By definition, flooding occurs when the river discharge exceeds the channel carrying capacity, or by lateral inflows and direct precipitation. Tockner and Stanford [16] observed that the hydrological connection between the river and floodplain enables exchange of materials and energy as well as the migration of biota. Because of the dependence of floodplains on periodic flooding, hydrological alterations have a particularly strong impact on these ecosystems. Hydrological changes frequently result in a reduction in flood peaks, leading to less inundation and a smaller flooding frequency in the flooded areas [17]. The ecological consequences of flow alterations are system-specific [18], and include an overall decline in biodiversity [19], shifts in riparian vegetation zones [20], or enhanced salinization [21]. In the Anthropocene period of the earth's history, the human forcing of hydrological alterations is increasingly becoming significant. Tockner et al. [18] documentated that anthropogenic disturbance resulted in degradation of up to $90 \%$ of Europe's floodplains and losses in total wetland area of $53 \%$ in Europe and $60 \%$ in North America over a historical period of 60 years. For Africa, Mitsch and Gosselink [22] reported a 2\% loss of the wetland area due to human activity.

Analysis of the variability of stochastic, hydrologic phenomena has typically consisted in decomposing the time series into its deterministic and stochastic components using time-series modelling techniques [9]. Deterministic components include trends and periodicities, while stochastic components include random variations. Deterministic or stochastic models have been used as such, depending on the focus of research, to estimate the parameters of the mathematical relationships between the random variables and the probabilities of occurrence of events related to the stochastic phenomena. Under the natural flow paradigm, several authors have identified different measures for identifying the hydrological variability of rivers and have provided tools for classifying rivers according to their hydrological signature [23]. Providing more detail on the type of flow variation, Puckridge et al. [24] have stressed the general importance of water level variations even below the bank full stage (flow pulses), which might have significant influence on the habitat size and characteristics.

The flooding regime of the Zambezi floodplain has scarcely been investigated in the reality of stochastic variability of rainfall in Zambia. Against the backdrop of limited research on the vital ecosystem, the research was in order along the following lines of inquiry:

1) Is there significant variation in the river discharge for the Zambezi floodplain over a historical time period?

2) What are the integrated flow characteristics for the Zambezi floodplain based on observed discharges over a historical time period?

3) What is the impact of rainfall variability on the flooding regime of the Zambezi river floodplain?

Further to the exposition of the floodplain dynamics and the need for research into the Zambezi floodplain in this introductory section of the paper, the methodology is presented in Section II, which is followed by the results and discussion in Sections III and IV respectively. The terminal sections of the paper include the conclusion and recommendations.

\section{METHODOLOGY}

\section{A. Conceptual Framework}

The Zambezi floodplain is a wetland ecosystem occurring in the aquatic/terrestrial transition zone (ATTZ) that is periodically inundated by the lateral overflow of the Zambezi river. Based on the flood pulse concept and natural flow regime illustrated in Fig. 1, the floodplain can be considered as an integral part of the system that is periodically coupled and decoupled from the parent river by an annual flood pulse, which laterally exchanges water, nutrients and organisms between the river channel and the connected floodplain. The flood pulse is itself characterized by the magnitude, frequency, duration, timing and rate of change of water discharge over the floodplain. As such the flooding regime of the Zambezi floodplain is conceptualised as a hydrologic signature of the river's discharge over time revealing variations as a function of the precipitation regime in the geomorphic and hydrologic spectrum. From this theoretical perspective, the impact of the stochastic variability of rainfall on the flooding regime of the Zambezi river floodplain can be measured by the sensitivity of the river discharge to rainfall.

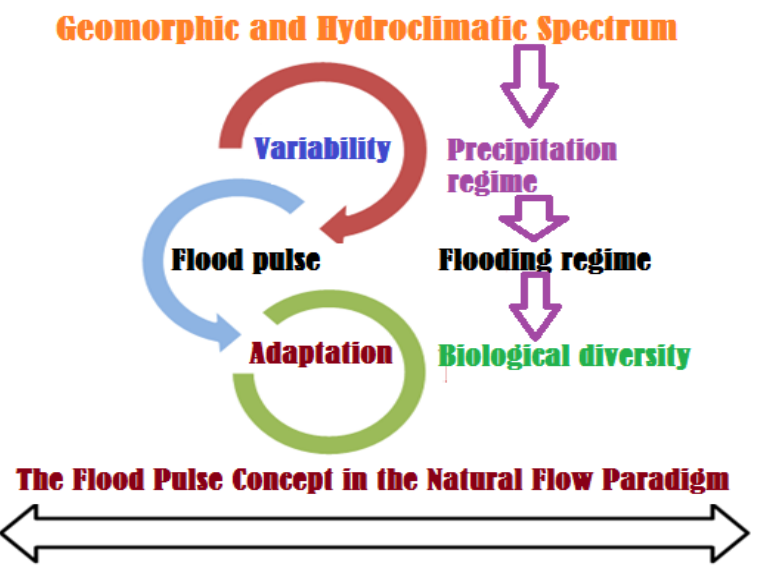

Fig. 1: Conceptual framework for the analysis of the Zambezi floodplain dynamics

\section{B. Study Area}

The study area for the research is the Zambezi floodplain, 
World Journal of Research and Review (WJRR)

ISSN:2455-3956, Volume-3, Issue-5, November, 2016 Pages 22-28

which occurs along the Zambezi River in the Western Province of Zambia. Zambia is a land-locked country located in central Southern Africa between latitude $13.1339^{\circ}$ South and longitude, $27.8493^{\circ}$ East. The characteristics of the study area are described in terms of topographic (see Fig.2) and climatologic characteristics.

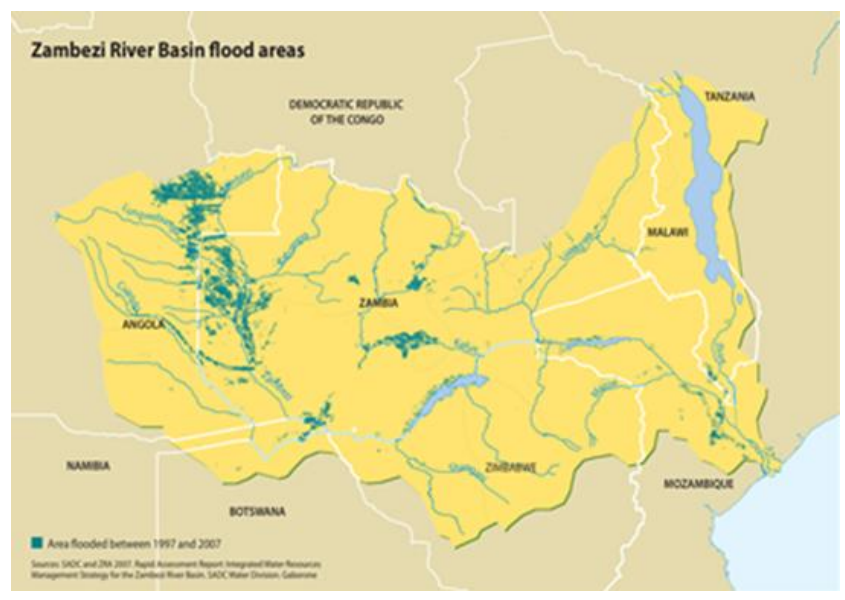

Fig.2: The Zambezi river basin flooding areas (Source: GRID-Arendal, 2007)

The floodplain stretches from the Zambezi's confluence with the Kabompo and Lungwebungu Rivers in the north, to a point about $230 \mathrm{~km}$ south, above the Ngonye falls and south of Senanga. To the south around the Ngonye Falls, harder rock is found at the surface and has resisted the river's tendency to cut a channel down into it, and so acts a bit like a dam. Behind it the floodplain is formed. Below the falls, the river falls nearly twice as fast as it does on the plain, and flows more swiftly in a narrower valley less prone to flooding. Along most of its length its width is over $30 \mathrm{~km}$, reaching $50 \mathrm{~km}$ at the widest, just north of Mongu, principal town of the plain, situated at its edge. The main body of the plain covers about $5500 \mathrm{~km}^{2}$, but the maximum flooded area is $10,750 \mathrm{~km}^{2}$ when the floodplains of several tributaries are taken into account [25].

Generally, Zambia's climate on an altitude ranging between 1,000 and 1,300 metres is characterized by three distinct seasons (see Table I). Rainfall over the Zambezi river basin varies from $500 \mathrm{~mm}$ in the extreme south and southwest part of the basin to more than $1,400 \mathrm{~mm}$ in the Upper Zambezi and Kabompo sub-basins, in the north-eastern shores of Lake Malawi/Nyasa/Niassa in Tanzania, and in the southern border area between Malawi and Mozambique occurrence [26]. This rainfall distribution has been associated with seasonal flooding of the Zambezi river. The peak of the flood usually occurs in April after the peak of the rainy season in January-February. The flood recedes in May to July leaving behind a fertile grey to black soil overlaying the Kalahari sands, enriched by silt deposited by the flood as well as humus from vegetation killed by the initial flood, and from decaying aquatic plants left to dry out in the mud [25].

\begin{tabular}{|c|c|c|c|}
\hline Season & Period & $\begin{array}{c}\text { Mean } \\
\text { Daily } \\
\text { Maximum } \\
{ }^{\circ} \mathbf{C} \\
\end{array}$ & $\begin{array}{c}\text { Mean } \\
\text { Daily } \\
\text { Minimum } \\
{ }^{\circ} \mathbf{C} \\
\end{array}$ \\
\hline $\begin{array}{c}\text { Cool and } \\
\text { dry }\end{array}$ & May-August & $21-26$ & 6-12 \\
\hline $\begin{array}{l}\text { Hot and } \\
\text { dry }\end{array}$ & September-October & $28-35$ & $17-22$ \\
\hline $\begin{array}{l}\text { Warm } \\
\text { and rainy }\end{array}$ & November-April & $25-30$ & $14-19$ \\
\hline
\end{tabular}

\section{Data Collection and Analysis}

The research used secondary time-series data on annual rainfall and discharge over a period of 50 years from 1965-2014 inclusive. The rainfall data were collected from the Zambia Meteorological Department, while the discharge data were collected from the Ministry of Energy and Water Development. In line with the objectives of the research, data analysis consisted in estimating the temporal characteristics of discharge followed by flow duration analysis of river discharge leading to quantification of the sensitivity of the Zambezi floodplain to rainfall. The methods of data analysis are described in the following sub-sections.

\section{Flow Variability Analysis}

The temporal variability of flow or discharge for the Zambezi floodplain was estimated using a variability index based on the mean and standard deviation, which is expressed as:

$$
\delta_{i}=\frac{\left(x_{i}-\mu\right)}{\sigma}
$$

(1)

Where, $\delta \mathrm{i}$ is variability index for year $\mathrm{i} ; \mathrm{X}_{\mathrm{i}}$ is annual discharge for year $i ; \mu$ is the mean; and $\sigma$ is standard deviation.

\section{Spectral Analysis}

Spectral analysis was used to identify hidden periodicities in the time series distribution of discharge. The objective of spectral analysis is to decompose the time-series into harmonic, sine wave components. The sine wave component is given by Equation 2.

$$
f(x)=\mu+\sum_{i=1}^{L}\left(\lambda_{i} \sin \frac{2 \pi t i}{T}+\phi_{i}\right)+\varepsilon_{i}
$$

Where, $\mu$ is the population mean, $\lambda \mathrm{i}$ is amplitude of the wave, $\phi i$ is phase of the wave, and $i / T$ is the frequency of the wave. The result of spectral analysis is the spectral density function or spectrum, which is usually presented in a graphic form called a periodogram. In this research, the discharge data are subjected to spectral analysis in order to detect the inherent periodicities.

\section{Flow Duration Analysis}


Flow duration analysis (FDA) in hydrological assessments consists in fitting a relatively long chronological record of flow data to an exceedance probability distribution. The FDA is more robust when longer periods of hydrologic data records can be used [27]. This study computed the exceedance probabilities for a 50-year record of discharge series using Equation 3.

$$
p=\frac{m}{n+1}
$$

Where, $\mathrm{p}$ is probability of exceedance, $\mathrm{m}$ is rank of a given flow in the ordered series, and $\mathrm{n}$ is the number of observations. The flow exceedance probability curve is then developed by plotting the probabilities against flow values. The resultant curve reflects the integrated hydrologic characteristics of a catchment area.

\section{Sensitivity Analysis}

The sensitivity of the Zambezi floodplain to rainfall is quantified using the precipitation elasticity of streamflow [28] and [29], which is the relative change in mean annual discharge divided by the relative change in mean precipitation as given by Equation 4.

$$
\varepsilon_{P}=\operatorname{median}\left[\frac{\left(Q_{i}-\bar{Q}\right)}{\left(P_{i}-\bar{P}\right)} \frac{\bar{P}}{\bar{Q}}\right]
$$

Where, $\mathrm{P}_{\mathrm{i}}$ is the annual precipitation in year $\mathrm{i}, \mathrm{P}^{-}$is the mean annual precipitation, Qi is annual discharge in year $\mathrm{i}, \mathrm{Q}^{-}$is mean annual discharge, and $i$ is year of the time period.

\section{RESULTS}

\section{A. Temporal Variability of Flow}

\section{Variability of Flow}

The first line of inquiry for the research was to assess whether there was significant variation in the river discharge for the Zambezi floodplain over a historical time period. Using the variability index based on the mean and standard deviation of the discharge time series, the inter-annual fluctuations in the discharge were computed and visualized graphically (see Fig. 3). Visual inspection of the graph suggests a high degree of low flow variation in the period from 1990 to 2007.

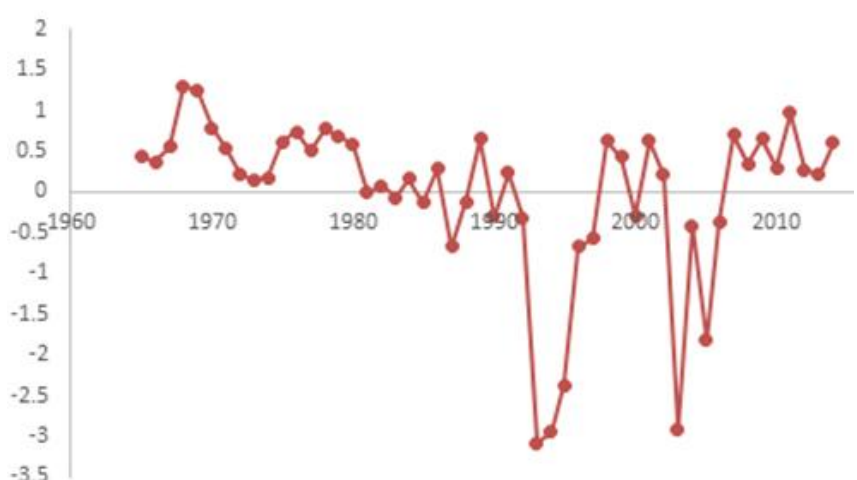

Fig. 3: Flow variability of the Zambezi floodplain:1965-2014

In the general sense, a quantitative estimate of the degree of departure from the long-term average is $21 \%$ as can be seen from Table II highlighting the coefficient of variation among other descriptive statistics of the discharge.

Table II: Descriptive statistics of discharge time series for the Zambezi floodplain

\begin{tabular}{l|c}
\hline Statistic & Discharge (cumecs) \\
\hline No. of observations & 50 \\
Minimum & 171.4 \\
Maximum & 634.6 \\
Median & 524.1 \\
Mean & 497.3 \\
Standard deviation (n-1) & 105.9 \\
Coefficient of variation & $\mathbf{0 . 2 1 1}$ \\
Skewness (Pearson) & -1.859 \\
Kurtosis (Pearson) & 3.019 \\
\hline
\end{tabular}

\section{Periodicity of Flow}

The spectral density of the hydro-climatic signal was plotted against the scaled frequency (see Fig. 4) for the purpose of detecting any periodicities in the time series based on the frequencies corresponding to the peak values of the dominant periodicities.

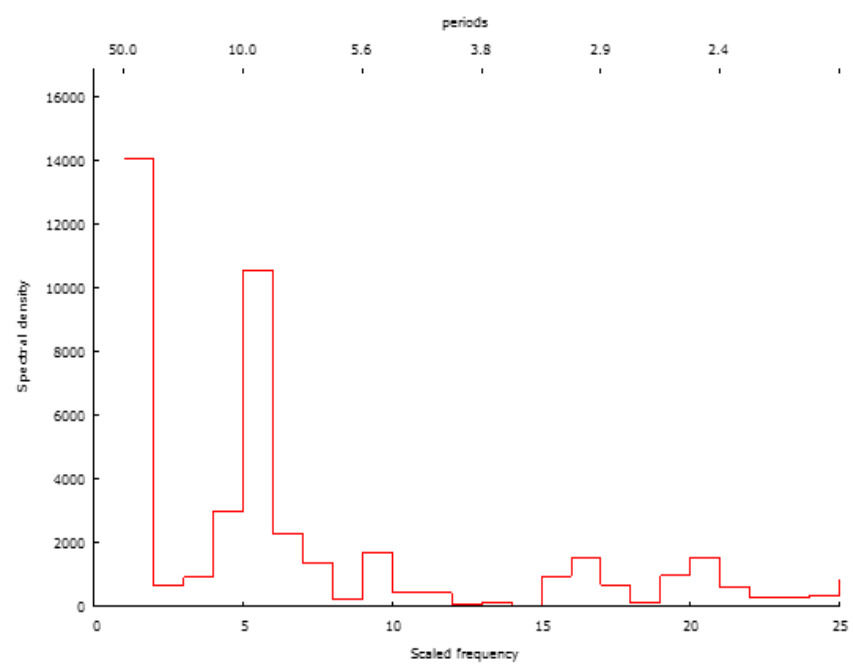

Fig. 4: Periodicity of discharge in the Zambezi floodplain

The spectral signature of the discharge hydro-climatic signal reveals a frequency of 0.125 corresponding to a periodicity of 10 years.

\section{B. Characterization of the Flow Regime}

Analysis of the integrated flow characteristics for the Zambezi floodplain is based on the observed discharges at the Chavuma National Gauge Station (CGS). This is the main gauge station before the floodplain. The next major gauge station along the Zambezi river is in Livingstone before the Victoria falls. The integrated components of flow including 
magnitude, frequency, duration, timing and rate of change of discharge are represented by a flow duration curve, which was generated for the study as presented in Fig. 5.

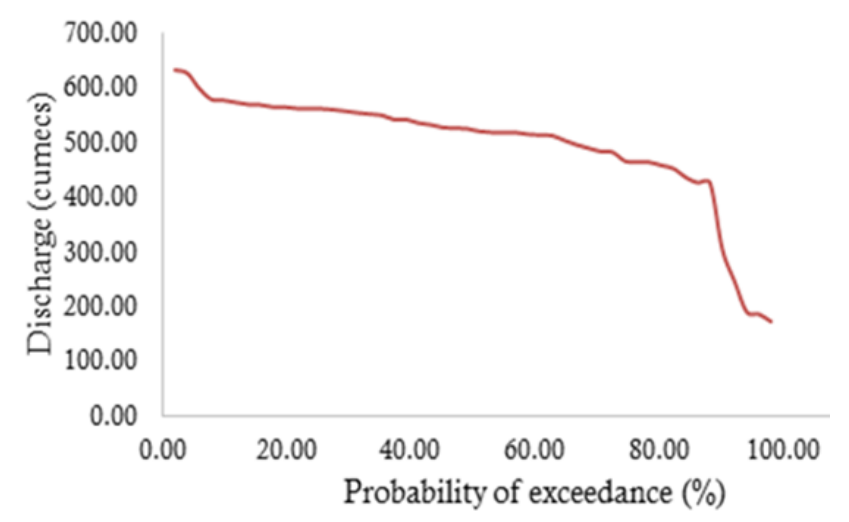

Fig. 5: Flow duration curve for the Zambezi river floodplain

A flow duration curve characterizes the ability of the basin to provide flows of various magnitudes, and its shape is determined by the hydrologic and geomorphic characteristics of the drainage area. The shape of a flow-duration curve in its upper and lower regions is particularly significant in evaluating the river basin characteristics. In the high-flow region of the curve in Fig. 6, there appears to be a slightly steep curve indicating high flows for a relatively short period with a high propensity to cause flash floods. A significant portion of the curve has a gentle slope indicating that moderate flows are sustained throughout the years. The shape of the low-flow region appears to be very steep which indicates a period of low contribution from surface and groundwater sources.

\section{Precipitation Elasticity of Streamflow}

A hydrograph along with a time series plot of rainfall was generated for the discharge time series in order to visualize the variations in the two hydro-climatic variables. The graphs in Fig. 6 show that there is alternating increase and decrease in the values of the discharges and rainfall amounts from 1965 to 2014.

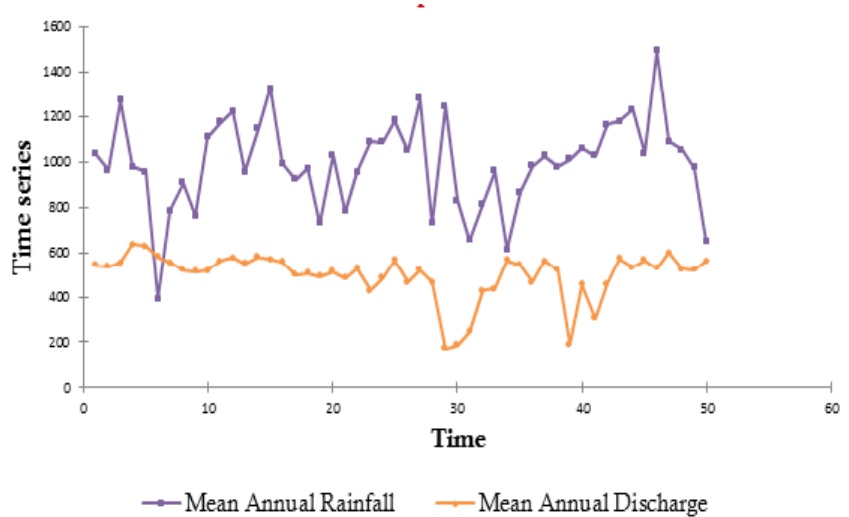

Fig. 6: Time series visualization of discharge and rainfall for the Zambezi floodplain
There is also correspondence between periods of high rainfall regimes and periods of high flooding regimes. However, the year 1987 recorded an increase in rainfall amount, but a drop in the discharge levels. The years 2004 and 2005 also indicated a reduction in discharge despite the rainfall values taking an upward swing. The deviation from the general trend observed in 1987, 2004 and 2005 could be attributed to the missing data for water levels that wasn't recorded for some periods. For the purpose of assessing the sensitivity of discharge to rainfall, the precipitation elasticity of streamflow was computed for the rainfall and discharge time series. The elasticity value was found to be 0.03 . This meant that there was a $3 \%$ change in the discharge values for $100 \%$ change in the rainfall values (see Table III). The result suggests that the discharge was not highly sensitive to rainfall for the period under review.

Table III: Summary statistics of rainfall and discharge for computation of the Precipitation elasticity of streamflow for the Zambezi floodplain

\begin{tabular}{lccc}
\hline Variable & $\begin{array}{c}\text { Mean } \\
\text { Annual } \\
\text { Rainfall } \\
(\mathbf{m m})\end{array}$ & $\begin{array}{c}\text { Mean } \\
\text { Annual } \\
\text { Discharge } \\
\left(\mathbf{m}^{\mathbf{3}} / \mathbf{s}\right)\end{array}$ & $\begin{array}{c}\text { Precipitation } \\
\text { Elasticity of } \\
\text { Streamflow }\end{array}$ \\
\hline Mean & 994.336 & 497.323 & - \\
Median & 1002.70 & 524.120 & $\mathbf{0 . 0 3 1}$ \\
Minimum & 392.400 & 171.390 & - \\
Maximum & 1494.60 & 634.570 & - \\
\hline
\end{tabular}

\section{DISCUSSION}

The central hypothesis for this research was that there was no significant change in the flooding regime of the Zambezi floodplain in response to rainfall variability. Exploratory data analysis revealed a notable variation in discharge in the order of $21 \%$, thus defying the assumption of stationarity by which the statistical parameters of the time series hydro-climatic variables were deemed invariant over a historical period of 50 years. The variability of flow appeared to correspond with the rainfall variations during the same period as expected. However, the flow regime as depicted by the flow duration curve was found to be insensitive to the rainfall variability. This was evident from the gently sloping curve and the low precipitation elasticity of streamflow. The possible explanation for this is a substantial surface-groundwater contribution to river flow from the vast expanse of the Zambezi river basin, which transcends eight international boundaries within Southern Africa.

The use of the Precipitation elasticity of streamflow as a measure of sensitivity of flows to rainfall provides an alternative to hydrological modelling requiring several data sets, which may be scarcely available in certain river basins including the Zambezi. With merely annual rainfall and discharge times, a robust estimate of the sensitivity of the Zambezi floodplain ecosystem to hydro-climatic variability has been made. This is essential to water and environmental resources management as was intimated by Chiew et. al. [30] that estimates of the sensitivity of streamflow to climate are 
required to make informed decisions for managing water resources and environmental systems to cope with hydroclimatic variability and climate change. Thus, the significance of this research cannot be overemphasized.

In spite of the established evidence of robustness of discharge against the stochastic variability of rainfall in the Zambezi floodplain, a detailed hydro-geomorphic analysis is required to provide deeper insight into the changes in the flooding regime taking into account a broader spectrum of natural and anthropogenic forcing. This would help to quantify the flooding regime for integrated wetland management linking the dynamics of flooding to the biological diversity in the ecosystem.

\section{CONCLUSION}

This research assessed the impact of the stochastic variability of rainfall on the flooding regime of the Zambezi floodplain. This was justified by the need for more research into the changing dynamics of floodplain hydrology in the context of global environmental change. The research subscribed to the assumption of stationarity of the hydrologic time series. As such it was hypothesized that there were no significant variations in the floodplain discharge on account of rainfall variability. The study was conducted on a temporal scale of 50 years from 1965 to 2014 based on observed discharges at the Chavuma National Gauge Station. Statistical methods of data analysis were employed and included exploratory, frequency and sensitivity analysis techniques. The results of the analysis revealed significant inter-annual variation of $21 \%$ in the discharge time series with a dominant periodicity of 10 years in its sinusoidal discharge signal. The sensitivity of the discharge to rainfall was found to be insignificant with a very low precipitation elasticity of streamflow of 0.03 . In view of these findings, the conclusion of the study is that the flooding regime of the Zambezi river floodplain is seemingly robust against the variability of rainfall over time. However, further research needs to be undertaken to provide deeper insight into the changes in the flooding regime of the Zambezi floodplain taking into account a broader spectrum of natural and anthropogenic forcing, and to quantify the flooding regime for integrated wetland management linking the dynamics of flooding to the biological diversity in the ecosystem.

\section{ACKNOWLEDGMENT}

Special acknowledgments are paid to the individuals and organizations who made this work possible. The Zambezi River Commission and the Zambia Meteorological Department were extremely supportive in facilitating secondary data collection for the study area.

\section{REFERENCES}

[1] Fauchereau, N.. Rainfall Variability and Changes in Southern Africa during the 20th Century in the Global Warming Context. Natural Hazards. 2002, Vol. 29, 139-154.

[2] IPCC-Intergovernmental Panel on Climate Change. Climate Change: The Physical Science Basis. Contribution of Working Group 1 to the Fourth Assessment Report of the Intergovernmental Panel on Climate Change. S. Solomon, D. Qin, M. Manning, et al. (editors). Cambridge, United Kingdom and New York, NY, USA. 2007.
[3] Kirtman, B., Power, S. B., Adedoyin, J. A., Boer, G. J., Bojariu, R. Camilloni, I., Doblas-Reyes, F. J., Fiore, A. M., Kimoto, M., Meehl, G. A., Prather, M., Sarr, A., Schar, C., Sutton, R., van Oldenborgh, G. J., Vecchi, G. and H. J. Wang. Near-term Climate Change: Projections and Predictability. In: T. F. Stocker, D. Qin, G.-K. Plattner, et al. (editors). Climate Change 2013: The Physical Science Basis. Contribution of Working Group I to the Fifth Assessment Report of the Intergovernmental Panel on Climate Change. Cambridge, United Kingdom and New York, NY, USA. 2013.

[4] Hulme, M., Doherty, R., Ngara, T., New, M. and Lister, D. African climate change 1900-2100. Climate Research. 2001, Vol. 17, 145-168.

[5] Reason, C. J. C., W. Landman, and W. Tennant. Seasonal to decadal prediction of southern African climate and its links with variability of the Atlantic Ocean. Bulletin of the American Meteorological Society. 2006, Vol. 87 (7), 941-955.

[6] McSweeney, C. M., Lizcano, N.G. and Lu, X. The UNDP Climate Change Country Profiles Improving the Accessibility of Observed and Projected Climate Information for Studies of Climate Change in Developing Countries. Bulletin of the American Meteorological Society. 2010, Vol. 91, 57-166.

[7] Tadross, M., Suarez, P., Lotsch, A., Hachigonta, S., Mdoka, M., Ungani, L., Lucio, F., Kamdonyo, D. and Muchinda, M. (Growing-season rainfall and scenarios of future change in southast Africa: implications for cultivating maize. Climate Research. 2009, Vol. 40, 147-161.

[8] Christensen, J. H., Krishna Kumar, K., Aldrian, E., An, S.-I., Cavalcanti, I. F. A., de Castro, M., Dong, W., Goswami, P., Hall, A., Kanyanga, J. K., Kitoh, A., Kossin, J., Lau, N.C., Renwick, J., Stephenson, D. B., Xie, S.-P. and T. Zhou. Climate Phenomena and their Relevance for Future Regional Climate Change Supplementary Material. In: T. F. Stocker, D. Qin, G.-K. Plattner, et al. (editors) Climate Change 2013: The Physical Science Basis. Contribution of Working Group I to the Fifth Assessment Report of the Intergovernmental Panel on Climate Change. Cambridge, United Kingdom and New York, NY, USA. 2013.

[9] Jain, S. \& Singh, V. Water Resources Systems Planning and Management, Developments in Water Science 51. Amsterdam: Elsevier Science V.B. 2003.

[10] Poff, N.L.; David Allan, J.; Bain, M.B.; Karr, J. R.; Prestegaard, K.L Richter, B. D.; Sparks, R.E.; and Stromberg, J.C. The Natural Flow Regime: A paradigm for river conservation and restoration. BioScience. 1997, Vol. 47 (11), 769-784.

[11] Booth, E.; Mount, J.; and Viers, J. Flood Regime Characterization: A method to classify streamflow variability. American Geophysical Union. 2006, Fall Meeting, abstract \#H43E-0525.

[12] Costanza, R.; R d'Arge, R de Groot, S Farber, M Grasso, B Hannon. The value of the world's ecosystem services and natural capital. Nature. 1997, Vol. 387, 253-260

[13] Mitsch, W.J. and Gosselink, J.G. Wetlands. New York, USA, John Wiley \& Sons. 2000.

[14] Keddy, P.A., Lauchlan H. Fraser, Ayzik I. Solomeshch, Wolfgang J. Junk, Daniel R. Campbell, Mary T. K. Arroyo, And Cleber J. R. Alho. Wet and Wonderful: The World's Largest Wetlands Are Conservation Priorities. BioScience. 2009, Vol. 59 (1), 39-51.

[15] Junk, W.J., P.B. Bayley, and R.E. Sparks. The flood pulse concept in river-floodplain systems. p. 110-127. In D.P. Dodge [ed.] Proceedings of the International Large River Symposium. Can. Spec. Publ. Fish. Aquat. Sci. 1989, 106

[16] Tockner, K. and Stanford, J.A. Review of Riverine Flood Plains: Present State and Future Trends. Environmental Conservation. 2002, Vol. 29, 308-330.

[17] Ward, J.V. and Stanford, J.A. Ecological connectivity in alluvial river ecosystems and its disruption by flow regulation. Regulated Rivers. 1995, Vol. 11, 105-119.

[18] Tockner, K.A., Lorang M.S. and Stanford, J.A. River flood plains are model ecosystems to test general hydrogeomorphic and ecological concepts. River Research and Applications. 2010, Vol. 26: 76-86.

[19] Binn, S.E. and Arthington, A.M. Basic principles and ecological consequences of altered flow regimes for aquatic biodiversity. Environmental Management. 2002, Vol. 30 (4), 492-507.

[20] Toner, M., and Keddy, P. River hydrology and riparian wetlands: a predictive model for ecological assembly. Environmental Management. 1997, Vol. 22, 723-736.

[21] Nilsson, C. and Berggren, K. Alterations of riparian ecosystems caused by river regulation. BioScience. 2000, Vol. 50, 783-792.

[22] Mitsch, W.J. and Gosselink, J.G. Wetlands, 4th Edition. John Wiley \& Sons, Inc. 2007. 
World Journal of Research and Review (WJRR)

ISSN:2455-3956, Volume-3, Issue-5, November, 2016 Pages 22-28

[23] Richter B.D., Baumgartner J.V., Powell J. \& Braun D.P. A method for assessing hydrologic alteration within ecosystems. Conservation Biology. 1996, Vol. 10, 1163-1174.

[24] Puckridge J.T., Sheldon F., Walker K.F. \& Boulton A.J. Flow variability and the ecology of large rivers. Marine and Freshwater Research. 1998, Vol. 49, 55-72.

[25] IUCN. Barotse Floodplain, Zambia: local economic dependence on wetland resources: Case Studies in Wetland Valuation. 2003, No. 2.

[26] Chenje, M. (Ed.) State of the Environment Zambezi Basin.SADC/IUCN/ZRA/SARDC, Maseru/Lusaka/Harare. 2000.

[27] CDFW. Standard Operating Procedure for Flow Duration Analysis in California. Department of Fish and Wildlife Instream Flow Program Standard Operating Procedure CDFW-IFP-005. 2013, 17.

[28] Schaake, J. From climate to flow Climate Change and US Water Resources ed P E Waggoner (New York: John Wiley \& Sons). 1990, 177-206.

[29] Sankarasubramanian, A.; Vogel, R. and Limbrunner, J. Climate elasticity of streamflow in the United States Water Resources Res. 2001, Vol. 37, 1771-81.

[30] Chiew, F. H. S., PEEL, M. C.,. Mcmahon, T. A \& Siriwardena, L.W. Climate Variability and Change-Hydrological Impacts (Proceedings of the Fifth FRIEND World Conference held at Havana, Cuba, November 2006, IAHS Publ. 2006, 308.

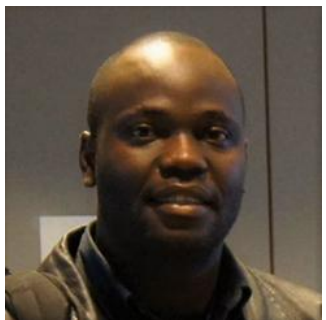

Mr. Joseph Thokozani Mwale is a Lecturer and Researcher at Mulungushi University (MU) in Kabwe, Zambia. He holds a Bachelor of Engineering Degree (1997-2004) of the University of Zambia, and a Master of Science Degree in Integrated Water Resources Management (2009-2010) of the University of Zimbabwe. Mr Mwale served as an Agricultural specialist in the Technical Services Branch of the Ministry of Agriculture from 2006 to 2011 before joining MU, where he is currently a Lecturer in the Department of Natural Resources. He specializes in water science and engineering for the optimum development and management of social-ecological systems.

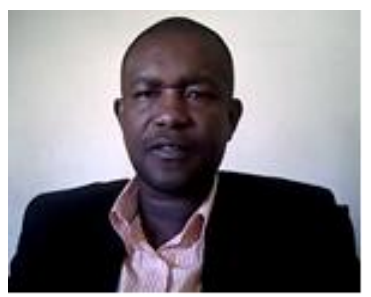

Mr. Idani Lichilo is an Agribusiness Lecturer and Researcher at Mulungushi University (MU) in Kabwe, Zambia. He obtained a Diploma in Agricultural Education at the Natural Resources Development College (NRDC) in 1992 and a Bachelor of Science in Agricultural Economics from the University of Zambia (UNZA) in 2003. He worked extensively as Secondary School Agriculture science teacher under the Ministry of Education before joining the then Ministry of Agriculture and Livestock where he was the District Agricultural Coordinator. Mr. Idani Lichilo was appointed Lecturer in the Department of Agriculture at MU in 2014. In pursuance of his academic path as a lecturer and researcher, he has taught several courses including Economics of Agricultural Markets, Agricultural project management, Agricultural Policy Analysis, Management of farm Enterprises, Management of Agricultural Cooperatives and Agricultural Development Economics at undergraduate level. He has also also been working and training small scale farmers around the university and elsewhere with agribusiness management skills in the market-oriented type of production.

Racheal Luneta is a currently graduating in the Degree of Bachelor of Land and Water Resources Management Programme offered by the School of Agriculture and Natural Resources at Mulungushi University, Zambia. 